\title{
COPD assessment test score and serum C-reactive protein levels in stable COPD patients
}

\author{
This article was published in the following Dove Press journal: \\ International Journal of COPD \\ 8 December 2016 \\ Number of times this article has been viewed
}

\author{
Hyung Koo Kang 1,2,* \\ Kang Kim ${ }^{1, *}$ \\ Hyun Lee' \\ Byeong-Ho Jeong' \\ Won-Jung Koh' \\ Hye Yun Park' \\ 'Division of Pulmonary and Critical \\ Care Medicine, Department of \\ Medicine, Samsung Medical Center, \\ Sungkyunkwan University School \\ of Medicine, Seoul, ${ }^{2}$ Division of \\ Pulmonary and Critical Care \\ Medicine, Department of Internal \\ Medicine, Ilsan Paik Hospital, Inje \\ University School of Medicine, \\ Goyang, Gyeonggi, South Korea \\ *These authors contributed equally \\ to this work
}

\begin{abstract}
Background: An eight-item questionnaire of the COPD assessment test (CAT) is widely used to quantify the impact of COPD on the patient's health status. C-reactive protein (CRP) is associated with disease severity and adverse health outcomes of patients with COPD. This study aimed to evaluate the relationship between CAT score and serum CRP levels in stable COPD patients.
\end{abstract}

Methods: We evaluated the medical records of 226 patients with CAT and serum CRP measured within a week at Samsung Medical Center between October 2013 and October 2015.

Results: Serum CRP levels had a significantly positive relationship with CAT score (Spearman's $r=0.20, P=0.003)$. Patients with elevated serum CRP levels $(>0.3 \mathrm{mg} / \mathrm{dL})$ were significantly more likely to have CAT scores of $\geq 14$. The adjusted odds ratio for elevated serum CRP levels in total CAT score was 1.06 (95\% confidence interval, 1.02-1.09). Among CAT components, cough (adjusted $P=0.005$ ), phlegm (adjusted $P=0.001$ ), breathlessness going up hills/stairs (adjusted $P=0.005$ ), low confidence leaving home (adjusted $P=0.002$ ), and feeling low in energy (adjusted $P=0.019)$ were independently associated with elevated serum CRP levels.

Conclusion: In stable COPD patients, serum CRP levels were independently associated with total CAT score and CAT components related to respiratory symptoms, confidence leaving home, and energy.

Keywords: chronic obstructive pulmonary disease assessment test, C-reactive protein, quality of life, inflammation

\section{Background}

COPD is a chronic inflammatory lung disease characterized by progressive airflow limitation and parenchymal destruction. ${ }^{1}$ It often causes remarkable symptom burden, including chronic cough, sputum production, breathlessness, and exercise intolerance. ${ }^{1-3}$ The Global Initiative for Chronic Obstructive Lung Disease guideline recommends multiple symptomatic assessments rather than just measuring breathlessness with lung function. ${ }^{1}$ Among several questionnaires measuring health-related quality of life, the COPD assessment test (CAT) is widely used in routine practice. ${ }^{4-6}$ It is an easy and simple measurement with an eight-item questionnaire, which is designed to quantify the impact of COPD symptoms on the patient health status with scores of $0-40 .{ }^{4}$ In clinically stable COPD patients, the CAT is also closely related to the St George's Respiratory Questionnaire. ${ }^{7,8}$

C-reactive protein (CRP) is a representative systemic biomarker reflecting the total systemic burden of inflammation in individuals. ${ }^{9}$ Serum CRP is elevated in stable COPD, and it correlates with disease severity and adverse health outcomes of patients with mild-to-moderate COPD. ${ }^{10}$ The Copenhagen City Heart Study and Copenhagen General Population Study showed that increased levels of CRP and other systemic
Correspondence: Hye Yun Park Division of Pulmonary and Critical Care Medicine, Department of Medicine, Samsung Medical Center, Sungkyunkwan University School of Medicine,

8I Irwon-ro, Gangnam-gu, Seoul 0635I, South Korea

Tel +82 234103429

Fax +82 234103849

Email hyeyunpark@skku.edu
International Journal of COPD 2016:11 3137-3143

3137

Dovepress if in 1

http://dx.doi.org/10.21471COPD.S118153 (c) (i) (5) $2016 \mathrm{Kang}$ et al. This work is published and licensed by Dove Medical Press Limited. The full terms of this license are available at https://www.dovepress.com/terms.php cc. ${ }_{\mathrm{BY}} \mathrm{NC}$ and incorporate the Creative Commons Attribution - Non Commercial (unported, v3.0) License (http://creativecommons.org/licenses/by-nc/3.0/). By accessing the work you hereby accept the Terms. Non-commercial uses of the work are permitted without any further permission from Dove Medical Press Limited, provided the work is properly attributed. For permission for commercial use of this work, please see paragraphs 4.2 and 5 of our Terms (https://www.dovepress.com/terms.php). 
biomarkers were associated with increased risk of COPD exacerbations. ${ }^{11} \mathrm{CAT}$ score is also associated with patients at high risk of exacerbation and changes significantly during and after exacerbations. ${ }^{6,12-14}$ Moreover, an elevated CAT score at exacerbation reflects exacerbation severity. ${ }^{6}$ Regarding the relationship between CAT score and CRP, change in CAT score from baseline to exacerbation onset was positively correlated to change in serum CRP. ${ }^{6,13}$ However, the relationship between the CAT score and the serum CRP levels has not been adequately investigated in stable COPD patients. Thus, we sought to determine the association between CAT score and serum CRP levels in stable COPD patients.

\section{Methods}

\section{Subjects}

The medical records of 246 COPD patients who took the CAT and had serum CRP levels within 1 week from CAT, at the Samsung Medical Center outpatient clinic from October 2013 to October 2015, were retrospectively reviewed. Among them, 20 patients with moderate or severe exacerbation at CAT and serum CRP measurements were excluded, and a total of 226 stable COPD patients were included in the present study (Figure 1). The Institutional Review Board of Samsung Medical Center approved this study and waived the requirement for informed consent due to the retrospective nature of the study (IRB No. 2015-12-098).

\section{Measurements}

Demographic features, smoking history, comorbidities, and current medications, including inhalers, were obtained by reviewing available medical records on the day patients performed the CAT. Comorbidities including diabetes mellitus, hypertension, cardiovascular disease (CVD), asthma, tuberculosis destroyed lung, and bronchiectasis were reviewed. Patients with CVD were defined as patients

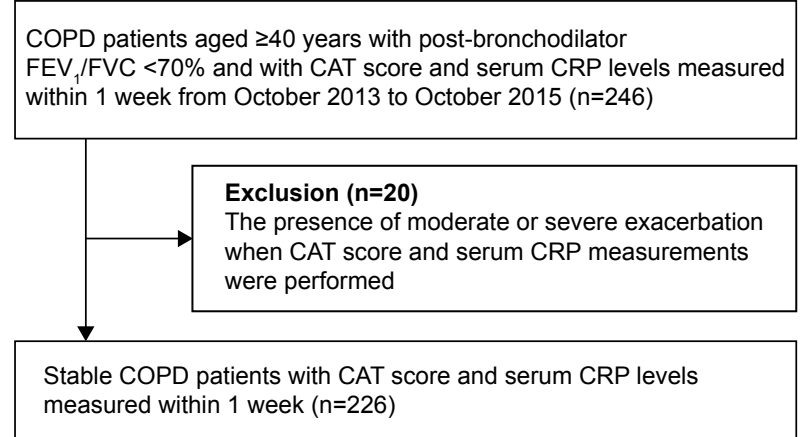

Figure I Flow chart for study enrollment.

Abbreviations: CAT, COPD assessment test; CRP, C-reactive protein; $\mathrm{FEV}_{1}$, forced expiratory volume in I second; FVC, forced vital capacity. who had been diagnosed with myocardial infarction, angina pectoris, stroke, and congestive heart failure, including cor pulmonale. Patients with stable COPD were defined as those without moderate or severe exacerbation when CAT score and serum CRP measurements were performed. The moderate or severe exacerbations were defined as a worsening of symptoms that required oral corticosteroids and/or antibiotics and/or hospitalization. ${ }^{15}$

Spirometry was performed according to the joint American Thoracic Society and European Respiratory Society guidelines. ${ }^{16}$ Absolute values of forced expiratory volume in 1 second $\left(\mathrm{FEV}_{1}\right)$ and forced vital capacity $(\mathrm{FVC})$ were obtained, and the percentage of predicted values ( $\%$ pred) for $\mathrm{FEV}_{1}$ and $\mathrm{FVC}$ were calculated from equations obtained in a representative Korean sample. ${ }^{17}$

The CAT consists of eight questions for cough, phlegm, chest tightness, breathlessness going up hills/stairs, activity limitations at home, confidence leaving home, sleep and energy. ${ }^{7}$ Each factor is presented on a semantic 6-point (0-5) differential scale, providing a total score of $40 .^{4}$

The value of serum CRP concentration measured within 1 week before or after CAT was selected for analysis. Serum CRP levels were measured using immunoturbidimetric assays (CRPL3, Roche Diagnostics, Indianapolis, IN, USA), and the analytical measurement range was $0.03-35 \mathrm{mg} / \mathrm{dL}$. The elevated serum CRP levels were defined when serum CRP levels were $>0.3 \mathrm{mg} / \mathrm{dL},{ }^{18}$ which is associated with increased risk of CVD. ${ }^{19,20}$

When subjects underwent more than one CAT and CRP during the study period, data from only the first measurement were used in this analysis.

\section{Statistical analysis}

Baseline characteristics are presented as medians and interquartile ranges (IQRs) for continuous variables and as numbers (\%) for categorical variables. Spearman's correlation and a linear model were used to assess the relationship between CAT score and serum CRP levels. Serum CRP values were dichotomized based on the upper limits of normal range $(0.3 \mathrm{mg} / \mathrm{dL})$ to evaluate the relationship between CAT score and increased serum CRP levels. The multiple logistic regression analyses were performed on age, sex, variables with $P<0.20$ based on univariate results (Table S1) or variables that were generally considered to be associated with CAT or elevated serum CRP levels. The number of comorbidities, including underlying lung disease, was also included as serum CRP levels can be elevated in chronic inflammation caused by noninfectious 
inflammation disorders. To determine the CAT score associated with elevated serum CRP levels $(>0.3 \mathrm{mg} / \mathrm{dL})$, CAT scores were dichotomized from 6 points to 24 points with 2-point intervals. Pearson's chi-square test was used for these dichotomous variables. All statistical analyses were performed using IBM SPSS Statistics for Windows, version 22.0 (IBM Corp., Armonk, NY, USA).

\section{Results \\ Clinical characteristics of subjects}

The clinical characteristics of study participants are summarized in Table 1. The study group included 198 males (87.6\%) and 28 females (12.4\%), with a median age of 70 years (IQR, $63-75$ years). The median body mass index (BMI) was $22.9 \mathrm{~kg} / \mathrm{m}^{2}$ (IQR, 20.3-25.0 kg/m²). Thirty-three patients (14.6\%) were lifetime never smokers. Median serum CRP level was $0.18 \mathrm{mg} / \mathrm{dL}$ (IQR, 0.07-0.57 mg/dL), and 88 patients $(38.9 \%$ ) had serum CRP levels $>0.3 \mathrm{mg} / \mathrm{dL}$. The median $\mathrm{FEV}_{1}$ (\% pred) was 56\% (IQR, 41\%-69\%), and

Table I Clinical characteristics of patients $(n=226)$

\begin{tabular}{|c|c|}
\hline Characteristics & $\begin{array}{l}\mathrm{N}(\%) \text { or } \\
\text { median (IQR) }\end{array}$ \\
\hline Age, years & $70(63-75)$ \\
\hline Male & $198(87.6)$ \\
\hline Body mass index, $\mathrm{kg} / \mathrm{m}^{2}$ & $22.9(20.3-25.0)$ \\
\hline \multicolumn{2}{|l|}{ Smoking status } \\
\hline Never & $33(14.6)$ \\
\hline Ex-smoker & $156(69.0)$ \\
\hline Current smoker & $37(16.4)$ \\
\hline \multicolumn{2}{|l|}{ Comorbidities } \\
\hline Hypertension & $67(29.6)$ \\
\hline Diabetes mellitus & $31(13.7)$ \\
\hline Cardiovascular disease & $34(15.0)$ \\
\hline Asthma & $39(17.3)$ \\
\hline TB destroyed lung & $22(9.7)$ \\
\hline Bronchiectasis & $32(14.2)$ \\
\hline Continuous oxygen therapy & $3(1.3)$ \\
\hline \multicolumn{2}{|l|}{ Biochemical measurements } \\
\hline C-reactive protein, $\mathrm{mg} / \mathrm{dL}$ & $0.18(0.07-0.57)$ \\
\hline C-reactive protein, $>0.3 \mathrm{mg} / \mathrm{dL}$ & $88(38.9)$ \\
\hline \multicolumn{2}{|l|}{ Lung function test } \\
\hline FVC, L & $3.01(2.46-3.69)$ \\
\hline FVC, \% pred & $76(63-88)$ \\
\hline $\mathrm{FEV}_{1}, \mathrm{~L}$ & $1.58(1.09-2.02)$ \\
\hline $\mathrm{FEV}_{\mathrm{l}}, \%$ pred & $56(4 \mid-69)$ \\
\hline $\mathrm{FEV}_{1}, \%$ pred $<50$ & $93(4 \mid .2)$ \\
\hline \multicolumn{2}{|l|}{ Medications } \\
\hline Inhaled long-acting muscarinic antagonist & $162(7 \mid .7)$ \\
\hline Inhaled long-acting beta2-agonist & $117(51.8)$ \\
\hline Inhaled corticosteroid & $95(42.0)$ \\
\hline Phosphodiesterase 4 inhibitor & $14(6.2)$ \\
\hline
\end{tabular}

Abbreviations: \% pred, percentage of predicted values; $\mathrm{FEV}$, forced expiratory volume in I second; FVC, forced vital capacity; IQR, interquartile range; TB, tuberculosis.
93 patients (41.2\%) had $\mathrm{FEV}_{1}$ (\% pred) $<50 \%$. The median number of comorbidities was 1 (IQR, 0-2). Median CAT score was 16 points (IQR, 9-22). The median scales of CAT components are shown in Figure 2.

\section{Relationship between CAT score and serum CRP levels}

Correlations between CAT component and serum CRP levels are shown in Table 2. The serum CRP levels had a significant positive relationship with total CAT score (Spearman's $r=0.199, P=0.003$ ). Among CAT components, serum CRP levels were significantly correlated with cough (Spearman's $r=0.153, P=0.021$ ), phlegm (Spearman's $r=0.184, P=0.006$ ), breathlessness going up hills/stairs (Spearman's $r=0.161$, $P=0.015$ ), low confidence leaving home (Spearman's $r=0.254, P<0.001$ ), and feeling low in energy (Spearman's $r=0.180, P=0.007)$. There were no significant relationships between serum CRP levels and chest tightness, activity limitations at home, or sleep (Table 3).

\section{Relationship between CAT score and elevated serum CRP levels}

As shown in Table 3, total CAT score was an independent factor associated with having elevated serum CRP levels after adjustment for covariates, including age, sex, BMI, smoking status, $\mathrm{FEV}_{1}(\%$ pred), and number of comorbidities (adjusted odds ratio [aOR], 1.06; 95\% confidence interval [CI], 1.02-1.09). The aORs of cough, phlegm, breathlessness, low confidence leaving home, and feeling low in energy for elevated serum CRP levels were 1.38 (95\% CI, 1.10-1.72), 1.38 (95\% CI, 1.13-1.68), 1.35 (95\% CI, 1.09-1.66), 1.29 (95\% CI, 1.09-1.52), and 1.25 (95\% CI, 1.04-1.50), respectively. Regarding relationship of elevated serum CRP levels with CAT component, there were no significant relationships between elevated serum CRP levels and chest tightness, activity limitations at home, or sleep.

\section{The points of total CAT score associated with elevated serum CRP levels}

The CAT scores were dichotomized from 6 points to 24 points with 2-point intervals. Patients with elevated serum CRP levels significantly increased from 14 points to 24 points compared with the other group (serum CRP level $\leq 0.3 \mathrm{mg} / \mathrm{dL}$ ). The $P$-values for elevated serum CRP levels with $14,16,18,20$, 22 , and 24 points were $0.012,0.004,0.003,0.034,0.003$, and $<0.001$, respectively. However, there were no significant relationships of elevated serum CRP levels with CAT scores of $6,8,10$, and 12 points (Figure 3 ). 


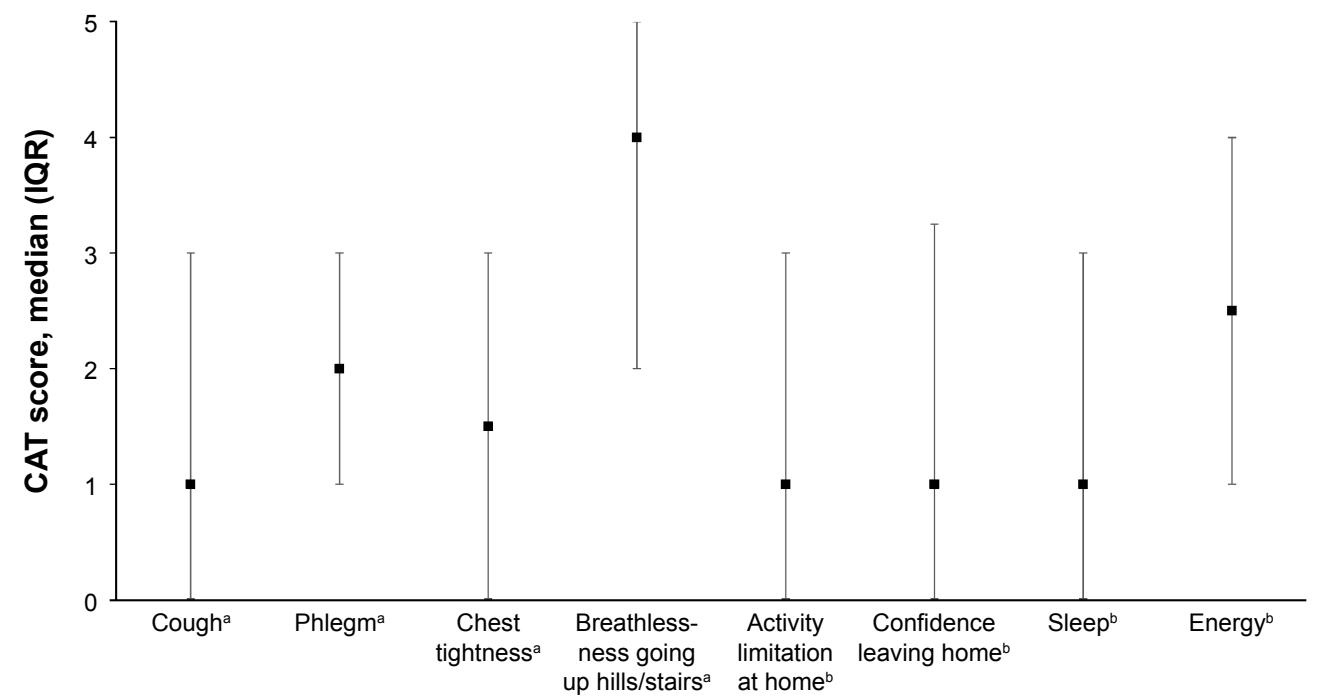

Figure 2 The scales of CAT components in 226 patients with stable COPD.

Notes: The score of each CAT component ranges from 0 to $5 .{ }^{a} \mathrm{CAT}$ component becomes severe when score goes to 5 . ${ }^{\mathrm{b}} \mathrm{CAT}$ component worsen when score goes to 5 . Abbreviations: CAT, COPD assessment test; IQR, interquartile range.

\section{Discussion}

In the present study, we found that serum CRP levels were independently associated with total CAT score in stable COPD patients. Among CAT components, this positive relationship was shown with cough, phlegm, breathlessness going up hills/stairs, low confidence leaving home, and feeling low in energy. The proportion of patients with elevated serum CRP levels significantly increased with 14 points of total CAT, suggesting that CAT score is a useful indicator to predict systemic inflammation in stable COPD patients.

CAT is a validated health status questionnaire designed to quantify the impact of COPD symptoms. ${ }^{4}$ Previous studies showed that this instrument provides reliable scores for predicting COPD exacerbation and severity, suggesting the CAT as a potential tool for the stratification of patients who are at risk for exacerbations. ${ }^{6,13,14}$ Systemic inflammation is measured by plasma fibrinogen and serum CRP, which are increased in COPD and aggravated during exacerbations. ${ }^{11}$ Accordingly, several studies demonstrated that CRP is elevated corresponding to increased CAT score during exacerbations. ${ }^{6,13}$ In stable COPD, our study showed that CAT score is also independently associated with elevated serum CRP levels even after adjusting for confounding factors, although this statistical relationship is weak. Elevated CRP levels can occur in association with chronic inflammation caused by noninfectious inflammation disorders, such as CVD, ${ }^{9,18,21}$ and patients with COPD often have significant extrapulmonary comorbidities contributing to symptoms. ${ }^{1}$ Thus, the number of comorbidities was additionally adjusted, and we found that the positive relationship between CAT score and serum CRP levels was preserved in stable COPD patients.

In particular, there are significantly more patients with elevated serum CRP levels, when CAT scores are $\geq 14$. According to the guidelines, a CAT score of $\geq 10$ or modified Medical Research Council (mMRC) grade $\geq 2$ is categorized as the "more symptomatic group". ${ }^{1}$ However, there is increasing recognition that a CAT cutoff value of 10 could overestimate the symptom severity compared with an mMRC cutoff value of 2. ${ }^{22,23}$ Recent data using the Korean COPD Subgroup Study (KOCOSS) cohort also reported that a CAT score of 15 is concordant with $\mathrm{mMRC}$ grade $\geq 2 .{ }^{24}$ This is in line with our findings showing a significant

Table 2 Correlation between COPD assessment test score and serum CRP levels

\begin{tabular}{|c|c|c|c|c|c|c|c|c|c|}
\hline & Cough $^{a}$ & Phlegm $^{a}$ & $\begin{array}{l}\text { Chest } \\
\text { tightness }^{a}\end{array}$ & $\begin{array}{l}\text { Breathlessness } \\
\text { going up hills/stairs }\end{array}$ & $\begin{array}{l}\text { Activity } \\
\text { at home }\end{array}$ & $\begin{array}{l}\text { Confidence } \\
\text { leaving home }^{b}\end{array}$ & Sleep $^{b}$ & Energy $^{b}$ & Total \\
\hline \multicolumn{10}{|l|}{ CRP } \\
\hline$R$ & 0.153 & 0.184 & 0.064 & 0.161 & 0.030 & 0.254 & 0.031 & 0.180 & 0.199 \\
\hline$P$-value & 0.021 & 0.006 & 0.335 & 0.015 & 0.649 & $<0.001$ & 0.645 & 0.007 & 0.003 \\
\hline
\end{tabular}

Notes: ${ }^{a} \mathrm{CAT}$ component becomes severe when score goes to 5 . ${ }^{\mathrm{b}} \mathrm{CAT}$ component worsen when score goes to 5 . Abbreviation: CRP, C-reactive protein. 
Table 3 Relationship between COPD assessment test score and elevated serum CRP levels ( $>0.3 \mathrm{mg} / \mathrm{dL})$

\begin{tabular}{|c|c|c|c|c|}
\hline CAT component & Unadjusted OR (95\% Cl) & $P$-value & Adjusted $\mathrm{OR}^{*}(95 \% \mathrm{Cl})$ & $P$-value \\
\hline Cough $^{\mathrm{a}}$ & $1.30(1.07-1.60)$ & 0.010 & $1.38(1.10-1.72)$ & 0.005 \\
\hline Phlegm ${ }^{a}$ & $1.33(1.11-1.6 I)$ & 0.002 & $1.38(1.13-1.68)$ & 0.001 \\
\hline Chest tightness $^{\mathrm{a}}$ & I.I $4(0.97-1.35)$ & 0.120 & $1.18(0.99-1.41)$ & 0.062 \\
\hline Breathlessness going up hills/stairs ${ }^{a}$ & $1.37(1.13-1.66)$ & 0.002 & $1.35(1.09-1.66)$ & 0.005 \\
\hline Activity limitations at home ${ }^{b}$ & $1.02(0.88-1.18)$ & 0.808 & $0.97(0.83-1.14)$ & 0.728 \\
\hline Confidence leaving home $\mathrm{e}^{\mathrm{b}}$ & $1.34(1.15-1.55)$ & $<0.001$ & $1.29(1.09-1.52)$ & 0.002 \\
\hline Sleep ${ }^{b}$ & I.I $4(0.97-1.34)$ & 0.106 & $1.14(0.96-1.35)$ & $0.14 \mid$ \\
\hline Energy ${ }^{\mathrm{b}}$ & $1.31(1.10-1.55)$ & 0.002 & $1.25(1.04-1.50)$ & 0.019 \\
\hline Total & $1.06(1.03-1.09)$ & 0.001 & $1.06(1.02-1.09)$ & 0.002 \\
\hline
\end{tabular}

Notes: *Adjusted for age, sex, body mass index, smoking, FEV , and number of comorbidities. ${ }^{a} \mathrm{CAT}$ component becomes severe when score goes to 5 . ${ }^{\mathrm{b}} \mathrm{CAT}$ component worsen when score goes to 5 .

Abbreviations: CAT, COPD assessment test; $\mathrm{Cl}$, confidence interval; CRP, C-reactive protein; FEV

relationship between elevated serum CRP levels and CAT scores of $\geq 14$.

In addition to total CAT score, we showed that certain CAT components related to respiratory symptoms (cough, phlegm, breathlessness going up hills/stairs), confidence leaving home, and energy were associated with increased levels of serum CRP. This is consistent with the characteristics of COPD, which is associated with an enhanced chronic inflammatory response in the airways, parenchyma, and pulmonary vasculature, ${ }^{25,26}$ and with low-grade systemic inflammation with increased levels of systemic inflammatory markers, such as CRP, fibrinogen, leukocytes, and TNF- $\alpha$. With interlinking relationships, the present study suggests that increased CAT score can reflect systemic inflammation as well as inflamed respiratory symptoms in stable COPD. ${ }^{27}$

Our study has several limitations. First, given the observational nature of the study, there is always the possibility that selection bias or confounding might have influenced our findings. Second, as blood samples were not collected for this study, we could not evaluate other systemic biomarkers, such as fibrinogen, interleukin- 6 , and TNF- $\alpha$. Further studies investigating the

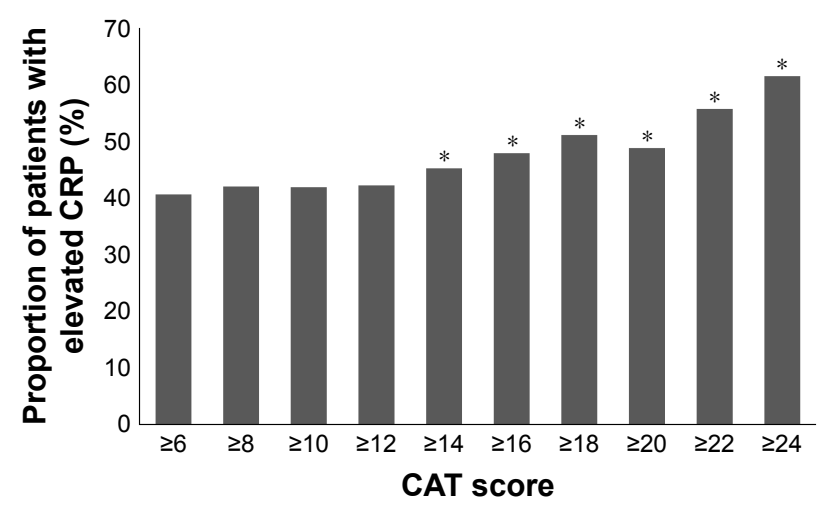

Figure 3 Proportions of patients with elevated serum CRP levels $(>0.3 \mathrm{mg} / \mathrm{dL})$ according to the CAT cutoff value.

Note: $* P$-value $<0.05$.

Abbreviations: CAT, COPD assessment test; CRP, C-reactive protein. relationships of those systemic biomarkers with CAT scores would be informative to reinforce the relationship between inflammation and CAT score in stable COPD patients. Third, because this is a cross-sectional study, further investigation is needed to determine intraindividual variation of the association between CAT scores and serum CRP levels over time.

\section{Conclusion}

In conclusion, this study demonstrated an independent association between CAT score and serum CRP levels in stable COPD patients. This relationship was most obvious in CAT components related to respiratory symptoms, confidence leaving home, and energy. The results suggest that CAT score can be a reliable indicator that incorporate both lung and systemic inflammation in stable COPD patients.

\section{Acknowledgments}

The authors would like to thank Soohyun Kim for electronic medical record development for this study. This study was supported by the Samsung Medical Center Foundation for Medical Research (SMO1140211).

\section{Disclosure}

The authors report no conflicts of interest in this work.

\section{References}

1. Global Initiative for Chronic Obstructive Lung Disease. Global strategy for the diagnosis, management and prevention of chronic obstructive pulmonary disease; 2016. Available from: http://www.goldcopd.org. Accessed May 1, 2016.

2. Kim V, Criner GJ. The chronic bronchitis phenotype in chronic obstructive pulmonary disease: features and implications. Curr Opin Pulm Med. 2015;21(2):133-141

3. O'Donnell DE, Lam M, Webb KA. Measurement of symptoms, lung hyperinflation, and endurance during exercise in chronic obstructive pulmonary disease. Am J Respir Crit Care Med. 1998;158(5 Pt 1): $1557-1565$.

4. Jones PW, Harding G, Berry P, Wiklund I, Chen WH, Kline Leidy N. Development and first validation of the COPD assessment test. Eur Respir J. 2009;34(3):648-654. 
5. Jones PW. COPD assessment test - rationale, development, validation and performance. COPD. 2013;10(2):269-271.

6. Mackay AJ, Donaldson GC, Patel AR, Jones PW, Hurst JR, Wedzicha JA. Usefulness of the Chronic Obstructive Pulmonary Disease Assessment Test to evaluate severity of COPD exacerbations. Am J Respir Crit Care Med. 2012;185(11):1218-1224.

7. Jones PW, Brusselle G, Dal Negro RW, et al. Properties of the COPD assessment test in a cross-sectional European study. Eur Respir J. 2011; 38(1):29-35.

8. Hwang YI, Jung KS, Lim SY, Lee YS, Kwon NH. A validation study for the Korean version of chronic obstructive pulmonary disease assessment test (CAT). Tuberc Respir Dis (Seoul). 2013;74(6):256-263.

9. Black S, Kushner I, Samols D. C-reactive protein. J Biol Chem. 2004; 279(47):48487-48490.

10. Man SF, Connett JE, Anthonisen NR, Wise RA, Tashkin DP, Sin DD. C-reactive protein and mortality in mild to moderate chronic obstructive pulmonary disease. Thorax. 2006;61(10):849-853.

11. Thomsen M, Ingebrigtsen TS, Marott JL, et al. Inflammatory biomarkers and exacerbations in chronic obstructive pulmonary disease. JAMA. 2013;309(22):2353-2361.

12. Jones PW, Harding G, Wiklund I, et al. Tests of the responsiveness of the COPD assessment test following acute exacerbation and pulmonary rehabilitation. Chest. 2012;142(1):134-140.

13. Tu YH, Zhang Y, Fei GH. Utility of the CAT in the therapy assessment of COPD exacerbations in China. BMC Pulm Med. 2014;14:42.

14. Lee SD, Huang MS, Kang J, et al. The COPD assessment test (CAT) assists prediction of COPD exacerbations in high-risk patients. Respir Med. 2014;108(4):600-608.

15. Rodriguez-Roisin R. Toward a consensus definition for COPD exacerbations. Chest. 2000;117(5 Suppl 2):398S-401S.

16. Miller MR, Hankinson J, Brusasco V, et al. Standardisation of spirometry. Eur Respir J. 2005;26(2):319-338.

17. Choi JK, Paek DM, Lee JO. Normal predictive values of spirometry in Korean population. Tuberc Respir Dis (Seoul). 2005;58:230-242.
18. Kushner I, Rzewnicki D, Samols D. What does minor elevation of C-reactive protein signify? Am J Med. 2006;119(2):166.e17-e28.

19. Pearson TA, Mensah GA, Alexander RW, et al. Markers of inflammation and cardiovascular disease: application to clinical and public health practice: a statement for healthcare professionals from the Centers for Disease Control and Prevention and the American Heart Association. Circulation. 2003;107(3):499-511.

20. Cushman M, Arnold AM, Psaty BM, et al. C-reactive protein and the 10-year incidence of coronary heart disease in older men and women: the cardiovascular health study. Circulation. 2005;112(1):25-31.

21. Libby P, Ridker PM. Inflammation and atherosclerosis: role of C-reactive protein in risk assessment. Am J Med. 2004;116(Suppl 6A): 9S-16S.

22. Jones PW, Adamek L, Nadeau G, Banik N. Comparisons of health status scores with MRC grades in COPD: implications for the GOLD 2011 classification. Eur Respir J. 2013;42(3):647-654.

23. Lee CH, Lee J, Park YS, et al. Chronic obstructive pulmonary disease (COPD) assessment test scores corresponding to modified Medical Research Council grades among COPD patients. Korean J Intern Med. 2015;30(5):629-637.

24. Rhee CK, Kim JW, Hwang YI, et al. Discrepancies between modified Medical Research Council dyspnea score and COPD assessment test score in patients with COPD. Int J Chron Obstruct Pulmon Dis. 2015;10: $1623-1631$.

25. Cosio MG, Saetta M, Agusti A. Immunologic aspects of chronic obstructive pulmonary disease. $N$ Engl J Med. 2009;360(23):2445-2454.

26. Hogg JC, Chu F, Utokaparch S, et al. The nature of small-airway obstruction in chronic obstructive pulmonary disease. $N$ Engl J Med. 2004; 350(26):2645-2653.

27. Gan WQ, Man SF, Senthilselvan A, Sin DD. Association between chronic obstructive pulmonary disease and systemic inflammation: a systematic review and a meta-analysis. Thorax. 2004;59(7):574-580. 


\section{Supplementary material}

Table SI Clinical characteristics according to serum CRP levels

\begin{tabular}{|c|c|c|c|}
\hline Characteristic & Serum CRP levels $\leq 0.3 \mathrm{mg} / \mathrm{dL}$ & Serum CRP levels $>0.3 \mathrm{mg} / \mathrm{dL}$ & $P$-value \\
\hline Age, years & $69(63-75)$ & 7II (64-76) & 0.25 \\
\hline Male & $119(86.2)$ & $79(89.8)$ & 0.43 \\
\hline Body mass index, $\mathrm{kg} / \mathrm{m}^{2}$ & $23.1(20.6-25.2)$ & $22.5(19.5-24.9)$ & 0.15 \\
\hline Smoking status & & & 0.23 \\
\hline Never & $18(13.0)$ & $15(17.0)$ & \\
\hline Ex-smoker & $93(67.4)$ & $63(71.6)$ & \\
\hline Current smoker & $27(19.6)$ & $10(11.4)$ & \\
\hline $\mathrm{FEV}_{1}, \mathrm{~L}$ & $1.68(1.19-2.07)$ & $1.41(0.92-1.91)$ & 0.01 \\
\hline Number of comorbidities & I (0-2) & I (0-2) & 0.97 \\
\hline
\end{tabular}

Notes: The data are presented as median and interquartile range, or as number (\%), and were compared using the Mann-Whitney U-test for continuous variables and Pearson's chi-squared test for categorical variables.

Abbreviations: CRP, C-reactive protein; $\mathrm{FEV}_{1}$, forced expiratory volume in I second.

\section{Publish your work in this journal}

The International Journal of COPD is an international, peer-reviewed journal of therapeutics and pharmacology focusing on concise rapid reporting of clinical studies and reviews in COPD. Special focus is given to the pathophysiological processes underlying the disease, intervention programs, patient focused education, and self management protocols.

\section{Dovepress}

This journal is indexed on PubMed Central, MedLine and CAS. The manuscript management system is completely online and includes a very quick and fair peer-review system, which is all easy to use. Visit $\mathrm{http}: / / \mathrm{www}$.dovepress.com/testimonials.php to read real quotes from published authors.

Submit your manuscript here: http://www.dovepress.com/international-journal-of-chronic-obstructive-pulmonary-disease-journal 